\title{
Diabetes: What Your Physician Doesn't Know
}

\section{Fourchalk Holly*}

Registered Herbal Therapist (RHT), Canada

Submission: October 10, 2018; Published: November 09, 2018

*Corresponding author: Fourchalk, Holly, Registered Herbal Therapist (RHT), Coquitlam, BC, Canada

Keywords: Diabetes, Physicians, Sugar, Pancreas, Insulin, Diet, Disease, Ayurveda medicine, Hypoglycemia, Metabolic disorder/prediabetes, Metformin

\section{Opinion}

Like physicians, most of us associate diabetes with being fat and/or with too much sugar. MDs usually go a little further and talk about your insulin receptors and your pancreas and insulin. Further, they think in terms of managing it. Today, most are open enough to say you can manage different levels of it with diet. And while they are correct, that is only a small piece to the puzzle.

First off, diabetes is a symptom not a disease. A diabetic profile can be due to your gut, your liver, your adrenals, even an infection! In fact, your gut, liver and adrenals are usually impacted long before your insulin receptors and the pancreas. But if you only focus on the end result, you will never resolve the cause and you of course, will be on medications for the rest of your life.

Are you aware that $80 \%$ of those people who are obese - do NOT have diabetes! Further, that many people who are thin do have diabetes. So, there must be a lot more involved in the process.

In old Ayurveda medicine, there are 20 different types of sugar metabolism disorders!! We have: hypoglycemia, metabolic disorder/prediabetes, diabetes types 1 and diabetes type 2 . That's it!!

The primary medication prescribed today is Metformin. Metformin is the synthetic version of an isolated compound called berberine that is found in a number of herbs that can actually eliminate diabetes 2 when utilized properly.

But the isolated, synthetic version can cause all kinds of problems because it depletes CoQ10 which is required on a cellular level to make fuel and consequently leaves you open to all kinds of issues:
a) Anxiety, shakiness
b) Blue/cold skin
c) Breathing issues
d) Chills
e) Cough/hoarseness
f) Decreased appetite

g) Depleted vitamin B12 (important for brain function; energy; removes homocysteine from the blood so you don't get inflamed arteries and heart disease; involved with healthy strong bones; prevents nerve damage - the myelin sheath that insulates and protects nerves); supports healthy DNA)

h) Depression

i) Diarrhea

j) Difficulties urinating

k) Dizziness

l) Drowsiness

m) Irregular heart beats

n) Low back pain or side pain

o) Muscle pain

p) Stomach pain (gas, nausea and vomiting)

What we need to do is:

a) Find out what is causing the diabetes: gut, liver, adrenals, infection, etc

b) Cellular functioning, ie., mitochondrial and methylation functioning

c) Then put together an individual protocol designed for you

Here's to you, your decision-making processes, and your health.

J Complement Med Alt Healthcare J 8(3): JCMAH.MS.ID.555740 (2018) 
This work is licensed under Creative Commons Attribution 4.0 License DOI: 10.19080/JCMAH.2018.08.555740
Your next submission with Juniper Publishers will reach you the below assets

- Quality Editorial service

- Swift Peer Review

- Reprints availability

- E-prints Service

- Manuscript Podcast for convenient understanding

- Global attainment for your research

- Manuscript accessibility in different formats ( Pdf, E-pub, Full Text, Audio)

- Unceasing customer service

Track the below URL for one-step submission https://juniperpublishers.com/online-submission.php 